Article

\title{
Comparisons of Acid and Water Solubilities of Rice Straw Ash Together with Its Major Ash-Forming Elements at Different Ashing Temperatures: An Experimental Study
}

\author{
Yi Zhang ${ }^{1} \oplus$, Guanmin Zhang ${ }^{1, *}$, Min Wei ${ }^{1}$, Zhenqiang Gao ${ }^{2,3}$, Maocheng Tian ${ }^{1}$ and \\ Fang $\mathrm{He}^{2, *}$ \\ 1 School of Energy and Power Engineering, Shandong University, Jinan 250061, Shandong, China; \\ zhy20360@163.com (Y.Z.); weimin@sdu.edu.cn (M.W.); tianmc65@sdu.edu.cn (M.T.) \\ 2 Department of Energy and Power Engineering, Shandong University of Technology, Zibo 255049, Shandong, \\ China; gaozq@sdut.edu.cn \\ 3 School of Energy and Power Engineering, Xi'an Jiaotong University, Xi'an 710049, Shanxi, China \\ * Correspondence: zhgm@sdu.edu.cn (G.Z.); hf@sdut.edu.cn (F.H.)
}

Received: 6 March 2019; Accepted: 31 March 2019; Published: 3 April 2019

\begin{abstract}
Recycling utilization of straw ash as a fertilizer in farmland is expected to play an important role in the sustainable development of both agriculture and biomass energy. However, the ashing temperature and the aqueous solution characteristics may affect the recycling properties of the nutrients contained in the ash. The solubilities of both the ash and its elements can represent the above recycling properties. This paper presents a systematic experimental investigation on the acid solubilities of both rice straw ash and its major elements produced from combustion at $400-800{ }^{\circ} \mathrm{C}$, and these findings are compared with the corresponding water solubilities obtained from the authors' previous work. Meanwhile, the correlations of two solubilities with the ashing temperature were given based on the experimental data. Results show that the acid solubility of rice straw ash decreases linearly by approximately $76 \%$ as the ashing temperature increases from 400 to $800{ }^{\circ} \mathrm{C}$, while it is significantly higher than the corresponding water solubility at different temperatures. The acid solubilities of $\mathrm{K}, \mathrm{P}, \mathrm{Ca}, \mathrm{Mg}$, and $\mathrm{Na}$ are higher than their water solubilities, whereas two solubilities of $\mathrm{S}$ and $\mathrm{Cl}$ have almost no dependence on the temperature and the acidity of solution. This study also reveals a strong negative linear relationship between the solubility of $\mathrm{K}$ and the temperature. The solubilities of other elements $(\mathrm{P}, \mathrm{S}, \mathrm{Na}, \mathrm{Ca}, \mathrm{Mg}$, and $\mathrm{Cl}$ ) with the temperature have quadratic curve or cubic curve relationships. Furthermore, it is recommended that the ashing temperature should be lower than $600{ }^{\circ} \mathrm{C}$ to avoid the loss of some nutrients in the straw ash.
\end{abstract}

Keywords: rice straw ash; ash-forming elements; solubility; sustainable development of both agriculture and biomass energy; recycling property; ashing temperature

\section{Introduction}

Applications of biomass ash have been attracting a lot of attention recently in various fields, such as farmland fertilizer [1-3], construction material [4,5], adsorbent material [6,7], production material of ceramics, and raw material of metal recovery $[7,8]$. In all these applications, the soil application as a green, cyclic, and sustainable way has a huger potential and better prospect $[9,10]$. According to the statistics, approximately $85-95 \%$ of nutrients taken up from soil by plants during growth—including potassium $(\mathrm{K})$, phosphorus $(\mathrm{P})$, calcium $(\mathrm{Ca})$, and magnesium $(\mathrm{Mg})$ - are contained in biomass ash [11]. The recirculation of these nutrients to farmland soil is important in agricultural 
sustainable development [12,13]. Furthermore, using biomass ash as an alternative to chemical fertilizer $[14,15]$ would not only balance the fertility of agricultural soil, but also reduce the amount of both the ash disposal and the chemical fertilizer of consumption, and thus alleviate loss of soil nutrients and environment pollution [16] and reduce the investment cost of agricultural production process. Comparing to direct straw returning, ash recirculation could prevent plants from being infected by pathogens and pests contained in the straw [17], and thus reduce the utilization of chemical pesticide. Therefore, the recycling of biomass ash as fertilizer to farmland soil plays a great role in the sustainable development of both agriculture and biomass energy.

In farmland soil, most of the nutrients are accessible to plants only in their free ionic form. One of the fundamental questions in the soil application of straw ash is transforming biomass ash to accessible (soluble or bioavailable) nutrients [18]. Therefore, the solubilities of biomass ash together with its major ash-forming elements are vital properties for the recirculation of nutrients, as shown in Figure 1. These solubilities are greatly determined by the $\mathrm{pH}$ values or acidity of solution and soil [11]. It is common knowledge that soil acidification is a serious global problem [19]. The main reasons for the soil acidification can be explained as follows: (1) the osmosis effect of the natural or artificial acidic rain resulting from dissolving of $\mathrm{CO}_{2}, \mathrm{SO}_{2}$, and $\mathrm{NO}_{\mathrm{x}}$ in air [20] and (2) the extensive application of chemical nitrogen fertilizers [7]. This seriously limits the sustainable development of eco-agriculture in the new era. According to the reference [19], 40-50\% of the potentially arable lands were acidic in the word. In China, the area of acid land (about 200 million ha) accounted for $23 \%$ of total land area [19]. Biomass ash contains various alkali metal compounds, which can improve acidic soil. As a result, the acid-soluble characteristics of both biomass ash and its ash-forming elements can partially represent the recycling property of the nutrients in the ash.

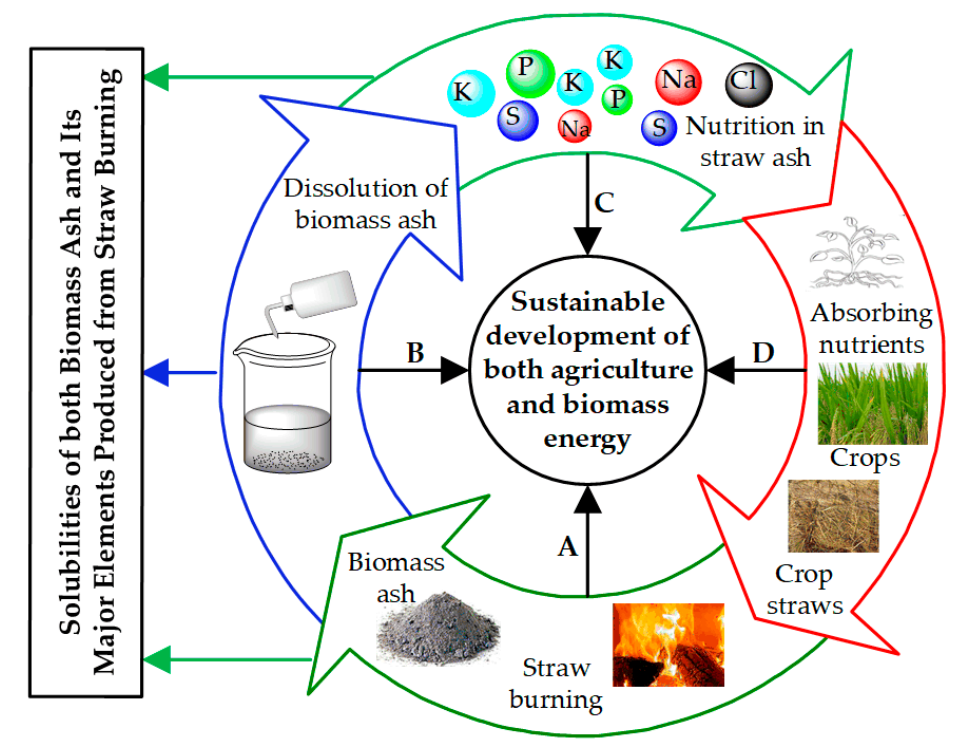

Figure 1. Schematic diagram of recycling application of biomass ash as a fertilizer in farmland.

The solubilities of both biomass ash and its ash-forming elements have been extensively reported in the published literatures. The total dissolved mass content of wood ash increased by $500 \%$ as the $\mathrm{pH}$ value of aqueous solution decreased from 13 to 5 [21]. In the bottom ash of municipal solid waste incineration, the solubilities of aluminum $(\mathrm{Al})$, calcium $(\mathrm{Ca})$, magnesium $(\mathrm{Mg})$, sulfur $(\mathrm{S})$, sodium $(\mathrm{Na})$, and iron $(\mathrm{Fe})$ in nitric acid solution $(\mathrm{pH}=4,6)$ increased significantly with the increase of the leaching time [22]. At the same time, the elements solubilities differ significantly with each other. Most of Ca and $\mathrm{Fe}, 30 \%$ of $\mathrm{K}, 32 \%$ of $\mathrm{Na}, 48 \%$ of $\mathrm{Al}, 25 \%$ of $\mathrm{S}$, and $48 \%$ of $\mathrm{P}$ in the solid residue of cane bagasse gasification were acid-soluble [23]. Moreover, in wood combustion ash, $81 \%$ of $\mathrm{Ca}, 57 \%$ of $\mathrm{Mg}, 34 \%$ of $\mathrm{K}$, and $20 \%$ of $\mathrm{P}$ were soluble in the ammonium acetate aqueous solution of $\mathrm{pH}=4.2$ [24]. In addition, based on their water solubilities, these elements were classified into the following three categories: 
(1) easily soluble nutrients (K, boron (B), $\mathrm{Na}$, chlorine $(\mathrm{Cl})$, and $\mathrm{S})$; (2) slightly soluble nutrients (Ca, $\mathrm{Mg}$, silicon ( $\mathrm{Si}), \mathrm{Fe}$, and $\mathrm{Al}$ ); and (3) highly insoluble nutrients (P) [22,25].

Rice is the third-largest agricultural product in the world. In China, rice accounts for about $40 \%$ of the total agricultural products according to the statistical data of Food and Agriculture Organization of the United States, meaning that a large amount of biomass ashes are produced from the burning of rice straw every year. Biomass ash properties are significantly affected by the combustion temperature or ashing temperature [26-32]. Effects of the temperature on the water solubilities of rice residue ashes or ash-forming elements have been investigated by some scholars. As reported by the references [17,33], after rice straw was pretreated at $300-1000{ }^{\circ} \mathrm{C}$ for $2 \mathrm{~h}$, the water-soluble $\mathrm{Si}, \mathrm{P}$, and $\mathrm{K}$ in the treated residues firstly increased and gradually decreased with increasing the heating temperature. According to our previous study [22], the water solubilities of both rice straw ash and rice husk ash decreased obviously with the increase of ashing temperature from $400{ }^{\circ} \mathrm{C}$ to $800{ }^{\circ} \mathrm{C}$. The water solubilities of $\mathrm{K}$ and $\mathrm{Na}$ contained in rice straw ash decreased with increasing the temperature, while those of $\mathrm{S}$ and $\mathrm{Cl}$ did not depend on the ashing temperature. In addition, $\mathrm{Si}, \mathrm{Ca}, \mathrm{Mg}$, and $\mathrm{P}$ contained in rice residue ashes prepared at different temperatures were almost insoluble in water [22].

As an important follow-up work of our previous study, this paper will present an investigation on the solubilities of rice straw ash together with major ash-forming elements in $20 \%$ acetic acid aqueous solution of $\mathrm{pH}=2.11$. Meanwhile, through the least square method, the functional relationship between the solubilities of rice straw ash together with its major elements and the ashing temperature will be established, aiming at providing a reference for the sustainable development of biomass energy and the developing of low-temperature biomass combustion equipment. In addition, based on the practical background of agricultural residues ashes in soil application, this study will attempt to clarify the effects of the ashing temperature on the recycling properties of the nutrients contained in rice straw ash in different solutions.

In the rest of this paper, we will firstly introduce the material and methods used in this study. Then, the characteristics of rice straw ash, and the acid solubilities of the ash together with its major ash-forming elements will be given and compared with the corresponding water solubilities obtained from the authors' previous work [22]. Finally, some main conclusions will be summarized and the future studies related to the utilization of biomass ash also will be proposed.

\section{Materials and Methods}

\subsection{Experimental Material}

The rice straw raw material used in this study was collected from farmland of rural area of Gaoqing County, Zibo City, Shandong Province, China. Then it was pulverized to the rice straw powder sample with the particle size $<1 \mathrm{~mm}$ using a blade pulverizer (DXF-20C) in Key Laboratory of Low-grade Energy and Waste Heat Utilization, Shandong University of Technology. The properties of the prepared rice straw powder are listed in Table 1 . To facilitate the pulverized process, the rice straw material was dried in a constant-temperature drying oven at $105^{\circ} \mathrm{C}$ for $12 \mathrm{~h}$. This also causes the moisture of the rice straw powder to be less than $4 \%$ as shown in Table 1 . It should be noted that in order to compare with the water solubility, the straw material used in this paper is the same as that in the authors' previous research.

Table 1. Properties of experimental rice straw material.

\begin{tabular}{cccccccc}
\hline \multirow{2}{*}{ Experimental Material } & \multicolumn{3}{c}{ Proximate Analysis (\%) } & \multicolumn{3}{c}{ Ultimate Analysis (\%) } \\
\cline { 2 - 8 } & Moisture & Volatiles & Ash & Fixed Carbon & C & H & O \\
\hline Rice straw & 3.6 & 68.9 & 13.2 & 14.3 & 42.4 & 6.9 & 48.8 \\
\hline
\end{tabular}




\subsection{Experimental Scheme}

\subsubsection{Selection of Ashing Temperature}

According to the published references $[34,35]$, the temperatures of the reactors in various biomass thermo-chemical conversion technologies are generally controlled within the range of $250-1200{ }^{\circ} \mathrm{C}$. The results of our pre-experimental study showed that (1) when the temperature was below $400{ }^{\circ} \mathrm{C}$, the colors of rice straw combustion residues were obviously black, indicating that the rice straw may not be completely combusted; and (2) when the temperature was above $800{ }^{\circ} \mathrm{C}$, almost all of the rice straw ash was sintered and adhered to the crucible bottom. The main components of sintered ash are silicate or aluminosilicate and it is difficult to be taken out from the crucible for further analysis and utilization [36,37]. In addition, most of the other components contained in straw are volatilized in the form of gas phase during the straw ashing at high temperature [38]. Therefore, we consider the temperature range of $400-800^{\circ} \mathrm{C}$ with the interval of $50{ }^{\circ} \mathrm{C}$ in this study.

In addition, the scanning electron microscopy (SEM) experiments of the rice straw ashes at $400{ }^{\circ} \mathrm{C}$ and $800{ }^{\circ} \mathrm{C}$ are employed to confirm whether the sintering phenomenon of rice straw ash happens.

\subsubsection{Selection of Residence Time}

Residence times of biomass fuels in various thermo-chemical conversion devices are different according to the literature. For example, the residence time varies from a few seconds to a few minutes in a fluidized bed [39], and from several minutes to a few hours in a grate-fired furnace [35]. During the proximate analysis of solid biomass fuel in a muffle furnace, the fuel usually can be kept for several hours [40].

According to the pre-experimental data in our previous work, when the residence time was more than $4 \mathrm{~h}$, the changes of the water solubilities of rice straw ashes were not significant at different ashing temperatures. Thus, in the presented work, the residence time is selected for $4 \mathrm{~h}$.

\subsection{Experimental Method}

\subsubsection{Ash Sample Preparation Process}

The rice straw ash sample was prepared in a muffle furnace at different ashing temperatures $\left(400-800^{\circ} \mathrm{C}\right)$. The ash preparation process is similar to that in our previous study [22], which can be summarized in the following five steps:

- Step 1: Approximately $5 \mathrm{~g}$ samples of the prepared rice straw powder sample were put into a crucible $(90 \times 60 \times 15 \mathrm{~mm})$.

- Step 2: The crucible being put the rice straw powder sample was heated in the muffle furnace from the room temperature to the experimental temperature with the heating rate of $10{ }^{\circ} \mathrm{C}$ per minute.

- Step 3: After staying $4 \mathrm{~h}$ at the experimental temperature, the muffle furnace was closed and cooled naturally to below $200{ }^{\circ} \mathrm{C}$.

- Step 4: The residual ash in the crucible was taken out to place in a desiccator with silica gel.

- Step 5: After being further cooled to the room temperature, the rice straw ash was sealed in a sample bag for analysis.

\subsubsection{Ash Dissolution Process}

The sample preparation process of the acid solubilities measurements of rice straw ash and its elements is shown in Figure 2. From Figure 2, as we can see that the dissolving process of the rice straw ash sample is mainly divided into four steps:

- Step 1: Approximately $0.5 \mathrm{~g}$ samples of the original rice straw ash were accurately weighed into the beaker. $25 \mathrm{~mL}$ of $20 \%$ acetic acid aqueous solution of $\mathrm{pH}=2.11$ was added to the sample and stirred in the beaker of $50 \mathrm{~mL}$ for $20 \mathrm{~min}$. 
- Step 2: After being stored overnight, the mixture consisting of ash and acetic acid aqueous solution was boiled for $2 \mathrm{~min}$, and then filtered using a quantitative filter paper with pore size of 30-50 microns.

- Step 3: The acid-insoluble rice straw ash was washed using deionized water ( $25 \mathrm{~mL}$ each time) five times. Subsequently, the acid-insoluble rice straw ash wrapped in the filter paper was dried in the constant-temperature drying oven at $105^{\circ} \mathrm{C}$ for $30 \mathrm{~min}$ and then it was burned at $550{ }^{\circ} \mathrm{C}$ for $2 \mathrm{~h}$ (according to the Chinese standard GB/T 8307-2002).

- Step 4: The acid-insoluble rice straw ash was weighted and kept in another sample bag for the measurement of element contents.

It should be noted that the dissolution experiments of the rice straw ashes at different ash-forming temperatures were repeated three times.

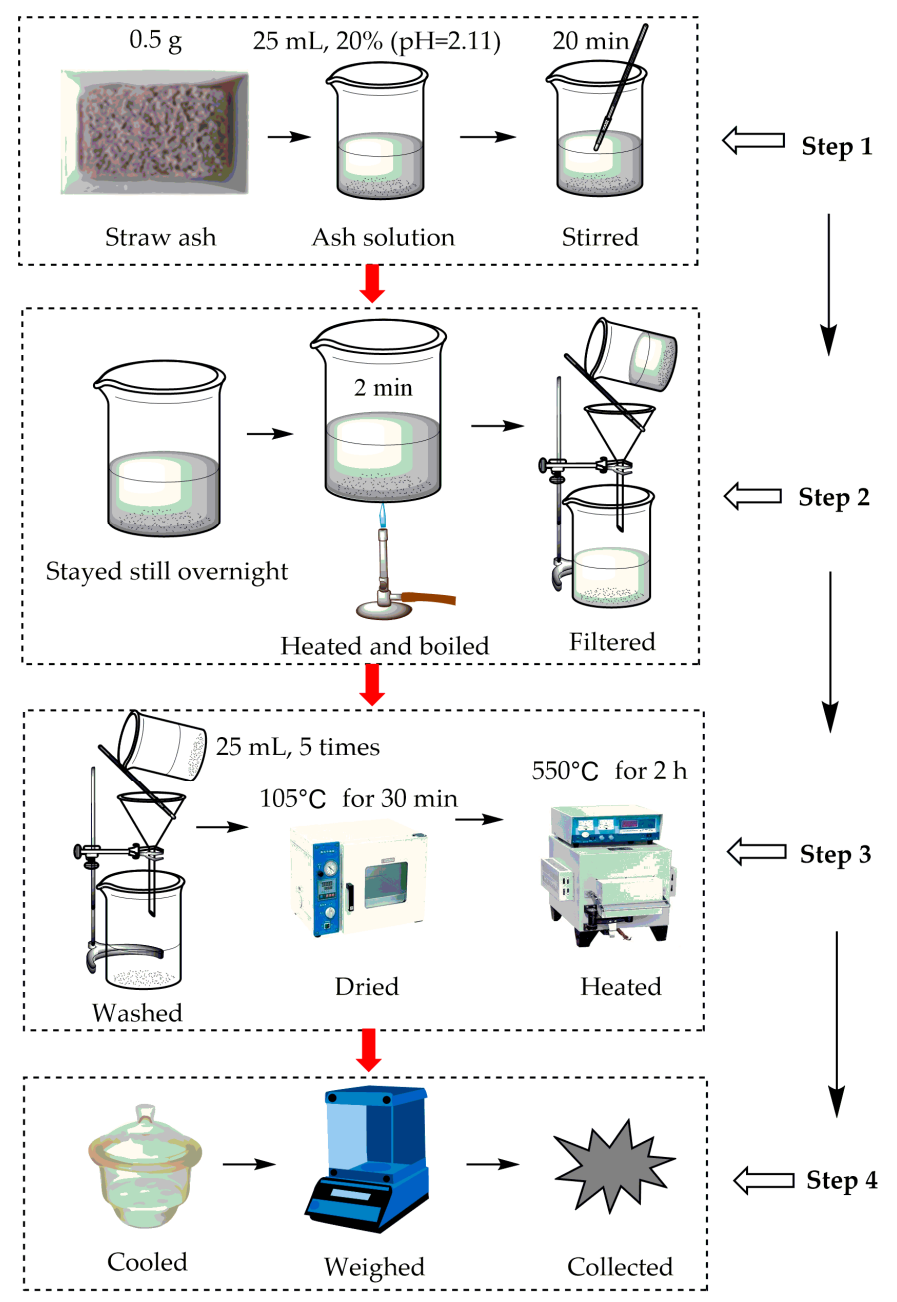

Figure 2. The dissolving process of rice straw ashes at different ashing temperatures.

\subsubsection{Element Content Measurement in Ashes}

A semi-quantitative $X$-ray fluorescence spectrometer $(X R F)$ is widely used to analyze inorganic non-metallic materials. The XRF can measure various kinds of elements contents in the sample of biomass ash at one time $[22,26,36,41]$. Thus, to obtain the solubilities of various main nutrient elements in the rice straw ash, these elements contents in the original rice straw ash and the acid-insoluble rice straw ash were measured using the semi-quantitative ZSX-100e XRF analyzer.

In our pre-test, tests were carried out in triplicate to determine the accuracy of XRF for measurement of elements in straw ash [42]. The results showed that the standard deviations for 
all elements were less than $1 \%$, illustrating that the results of each test are reliable. As a result, in the presented work, the XRF measurement of elements contents in the original ash and the acid-insoluble ash is only carried out once at different ashing temperatures.

\subsection{Experimental Data Processing}

According to the mass conservation of rice straw ash and its ash-forming elements before and after dissolution, the acid solubilities of rice straw ash together with its elements can be obtained using the above measurement data. It should be noted that the rice straw ashes from different ashing temperatures are taken as the research object in this paper. Thus, the volatilization of the elements is not taken into account during combustion when calculating the solubilities of ash and its major elements.

The acid solubility of the ash is the ratio of the mass of acid-soluble rice straw ash to the mass of original rice straw ash. It was calculated as

$$
\mathrm{AS}_{\mathrm{A}}=\left(1-m_{r} / m_{0}\right) \times 100 \%
$$

where $\mathrm{AS}_{\mathrm{A}}$ is the acid solubility of rice straw ash; $m_{0}$ and $m_{r}$ are the mass of original rice straw ash and acid-insoluble rice straw ash, respectively. It should be noted that the acid solubilities of the ashes at different temperatures were the average values of experiments repeated in triplicate.

The acid solubility of element $i$ in rice straw ash is the ratio of the acid-soluble mass of $i$ to the total mass of $i$ in the original rice straw ash. It was calculated using Equation (2).

$$
\mathrm{AS}_{\mathrm{A}, i}=\left[1-\left(m_{r} \times Y_{r, i}\right) /\left(m_{0} \times Y_{0, i}\right)\right] \times 100 \%
$$

where $\mathrm{AS}_{\mathrm{A}, i}$ is the acid solubility of element $i$ in rice straw ash; $Y_{r, i}$ and $Y_{o, i}$ are the mass fractions of element $i$ in the acid-insoluble rice straw ash and the original rice straw ash, respectively.

In addition, in order to further clarify the relationships between the solubilities of rice straw ash together with its elements and the ashing temperature, the correlation functions between both of them are given based on experimental data using least squares method.

Of note, in the authors' previous work [22], the dissolution process of rice straw ash in water, the methods of calculation of the water solubility of both rice straw ash and its elements have been given in detail. Therefore, in order to avoid the identical content, they were not given again in the materials and methods section in the presented work.

\section{Results and Discussion}

\subsection{Ash Characteristics}

\subsubsection{SEM Analysis}

The SEM images of the rice straw ashes prepared at $400{ }^{\circ} \mathrm{C}$ and $800{ }^{\circ} \mathrm{C}$ are shown in Figure 3a-f. As can be seen, the particles size of the rice straw ash prepared at $800^{\circ} \mathrm{C}$ are larger and more compact than that prepared at $400^{\circ} \mathrm{C}$, suggesting that ash sintering has occurred after the rice straw is kept at $800{ }^{\circ} \mathrm{C}$ for $4 \mathrm{~h}$. The ash sintering is referred to the bonding or welding of adjacent particles under the influence of the excess surface tension as shown Figure $3 g$ [43,44]. According to some previous works, it is also a phenomenon of the combination of particles caused by the synthetic effect of partial melting, viscous flow, and gas-solid chemical reactions [22,45]. Obviously, the rice straw ash with high sintering tendency is expected to have greater ash particle sizes.

In addition, the high alkali metals contents in rice straw ash can also accelerate the straw ash sintering [44], and the surface of sintered ash particle is smoother in comparison to unsintered ash. This resulted from the molten ash forming a coating and blocking up the holes on the surface of the ash particles [17]. As a result, some inorganic nutrients may be trapped inside rice straw ash particle at high combustion temperatures. 


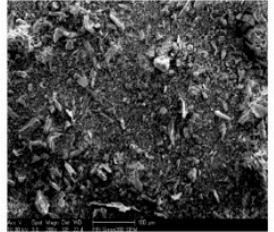

(a) $200 x$

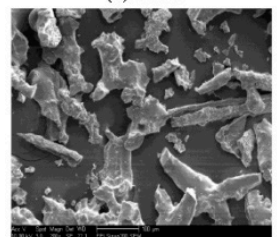

(d) $200 x$

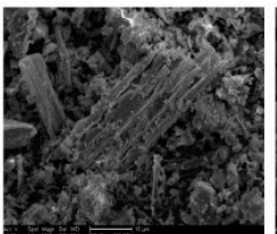

(b) $2000 \mathrm{x}$

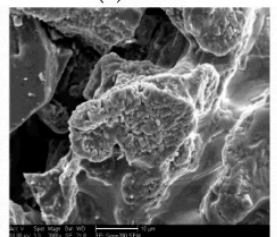

(e) $2000 x$

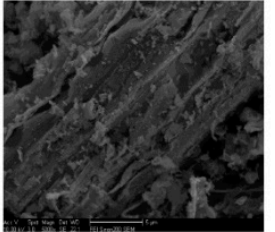

(c) $5000 x$

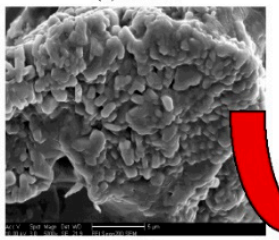

(f) $5000 x$

Figure 3. SEM images of rice straw ash at $400{ }^{\circ} \mathrm{C}(\mathbf{a}-\mathbf{c})$ and $800{ }^{\circ} \mathrm{C}(\mathbf{d}-\mathbf{f})$ and schematic of sintering phenomenon $(\mathbf{g})$.

\subsubsection{Ash-Forming Elements}

The XRF measurement results show that there are $\mathrm{O}, \mathrm{Si}, \mathrm{K}, \mathrm{Na}, \mathrm{Cl}, \mathrm{Ca}, \mathrm{Mg}, \mathrm{S}, \mathrm{P}, \mathrm{Fe}, \mathrm{Al}, \mathrm{Mn}$, $\mathrm{Ni}, \mathrm{As}, \mathrm{Br}, \mathrm{Sr}, \mathrm{Pb}, \mathrm{Rb}$, and $\mathrm{Ba}$ in both original rice straw ash and two insoluble rice straw ashes (the acid-insoluble ash and the water-insoluble ash [22]) at different ashing temperatures. Mass fractions of major ash-forming elements (more than $0.2 \%$ ) in these ashes, including $\mathrm{O}, \mathrm{Si}, \mathrm{K}, \mathrm{Na}, \mathrm{Ca}, \mathrm{Mg}, \mathrm{Cl}, \mathrm{P}$ and $\mathrm{S}$, are listed in Table 2.

Table 2. Mass fractions of major ash-forming elements in original and insoluble rice straw ashes at different ashing temperatures.

\begin{tabular}{|c|c|c|c|c|c|c|c|c|c|}
\hline \multicolumn{10}{|c|}{ Mass Fractions of Major Ash-Forming Elements in Original Rice Straw Ashes $(>0.2 \%)$} \\
\hline $\mathrm{T}\left({ }^{\circ} \mathrm{C}\right)$ & $\mathbf{O}$ & Si & $\mathbf{K}$ & $\mathrm{Na}$ & $\mathrm{Ca}$ & $\mathrm{Mg}$ & $\mathrm{Cl}$ & $\mathbf{P}$ & $\mathbf{S}$ \\
\hline 400 & 41.20 & 22.50 & 10.80 & 6.33 & 4.63 & 2.60 & 6.15 & 1.29 & 2.64 \\
\hline 450 & 40.50 & 23.00 & 11.30 & 6.15 & 4.50 & 2.69 & 6.11 & 1.32 & 2.63 \\
\hline 500 & 42.30 & 22.70 & 10.90 & 5.74 & 4.26 & 2.70 & 5.96 & 1.26 & 2.44 \\
\hline 550 & 41.50 & 23.00 & 10.90 & 5.91 & 4.51 & 2.76 & 5.55 & 1.33 & 2.22 \\
\hline 600 & 42.30 & 24.30 & 10.20 & 5.20 & 4.00 & 2.10 & 4.90 & 1.03 & 1.94 \\
\hline 650 & 40.80 & 23.80 & 11.30 & 5.04 & 4.95 & 1.90 & 4.90 & 1.09 & 1.72 \\
\hline 700 & 39.10 & 21.70 & 11.80 & 5.82 & 5.64 & 2.44 & 6.36 & 1.53 & 2.74 \\
\hline 750 & 44.30 & 26.00 & 9.07 & 6.04 & 5.35 & 2.26 & 0.55 & 1.14 & 2.89 \\
\hline 800 & 44.30 & 25.10 & 8.98 & 6.05 & 6.33 & 2.22 & 0.25 & 1.24 & 3.04 \\
\hline \multicolumn{10}{|c|}{ Mass Fractions of Major Ash-Forming Elements in Water-Insoluble Rice Straw Ashes (>0.2\%) } \\
\hline $\mathrm{T}\left({ }^{\circ} \mathrm{C}\right)$ & $\mathbf{O}$ & Si & K & $\mathrm{Na}$ & Ca & Mg & $\mathrm{Cl}$ & $\mathbf{P}$ & S \\
\hline 400 & 46.90 & 32.90 & 2.53 & 1.31 & 7.28 & 3.85 & 0.34 & 1.67 & 0.45 \\
\hline 450 & 51.50 & 29.80 & 3.19 & 1.97 & 5.62 & 3.39 & 0.47 & 1.43 & 0.53 \\
\hline 500 & 41.70 & 34.40 & 5.08 & 3.50 & 6.27 & 3.68 & 0.71 & 1.77 & 0.54 \\
\hline 550 & 42.50 & 31.80 & 6.03 & 3.97 & 6.12 & 3.51 & 1.17 & 1.69 & 0.64 \\
\hline 600 & 46.30 & 29.50 & 6.52 & 3.82 & 5.45 & 3.02 & 1.08 & 1.64 & 0.48 \\
\hline 650 & 46.70 & 29.00 & 7.06 & 3.85 & 4.98 & 3.15 & 1.31 & 1.45 & 0.46 \\
\hline 700 & 44.10 & 30.60 & 7.33 & 4.16 & 5.55 & 2.93 & 0.98 & 1.43 & 0.42 \\
\hline 750 & 44.00 & 31.30 & 7.43 & 4.14 & 5.32 & 2.90 & 0.76 & 1.40 & 0.41 \\
\hline 800 & 42.30 & 31.30 & 8.18 & 4.39 & 6.14 & 2.80 & 0.34 & 1.63 & 0.34 \\
\hline \multicolumn{10}{|c|}{ Mass Fractions of Major Ash-Forming Elements in Acid-Insoluble Rice Straw Ashes (>0.2\%) } \\
\hline $\mathrm{T}\left({ }^{\circ} \mathrm{C}\right)$ & O & Si & K & $\mathrm{Na}$ & $\mathrm{Ca}$ & $\mathrm{Mg}$ & $\mathrm{Cl}$ & $\mathbf{P}$ & $S$ \\
\hline 400 & 49.80 & 45.10 & 0.86 & 0.41 & 0.37 & 0.30 & 0.15 & 0.20 & 0.16 \\
\hline 450 & 46.10 & 41.40 & 3.07 & 2.93 & 1.78 & 1.01 & 0.62 & 0.26 & 0.29 \\
\hline 500 & 44.60 & 39.00 & 4.91 & 2.62 & 2.98 & 1.43 & 0.87 & 0.41 & 0.40 \\
\hline 550 & 46.20 & 34.20 & 5.68 & 3.39 & 3.65 & 1.95 & 0.98 & 0.81 & 0.46 \\
\hline 600 & 44.10 & 35.50 & 6.62 & 3.53 & 3.64 & 2.33 & 1.01 & 0.38 & 0.47 \\
\hline 650 & 47.50 & 32.20 & 6.95 & 3.40 & 3.57 & 2.41 & 0.97 & 0.47 & 0.43 \\
\hline 700 & 44.30 & 32.50 & 7.72 & 4.17 & 4.36 & 2.66 & 0.89 & 0.52 & 0.38 \\
\hline 750 & 48.60 & 31.50 & 6.70 & 2.97 & 4.04 & 2.81 & 0.45 & 0.37 & 0.41 \\
\hline 800 & 43.00 & 33.60 & 8.19 & 3.68 & 4.83 & 2.96 & 0.25 & 0.49 & 0.37 \\
\hline
\end{tabular}


From Table 2, it can be seen that the mass fractions of major ash-forming elements in the original rice straw ash at different ashing temperatures vary basically in the following decreasing order of quantity: $\mathrm{O}>\mathrm{Si}>\mathrm{K}>\mathrm{Na}>\mathrm{Cl}>\mathrm{Ca}>\mathrm{Mg}>\mathrm{S}>$ P. Also, the elements contents in both the acid-insoluble ashes and water-insoluble ashes vary in the following decreasing order of quantity: $\mathrm{O}>\mathrm{Si}>\mathrm{K}>$ $\mathrm{Ca}>\mathrm{Na}>\mathrm{Mg}>\mathrm{Cl}>\mathrm{P}>\mathrm{S}$ and $\mathrm{O}>\mathrm{Si}>\mathrm{K}>\mathrm{Ca}>\mathrm{Na}>\mathrm{Mg}>\mathrm{P}>\mathrm{Cl}>\mathrm{S}$, respectively. It should be noted that the contents of the individual elements (such as $\mathrm{Na}, \mathrm{Ca}, \mathrm{Mg}, \mathrm{Cl}$, and $\mathrm{P}$ ) in the original and insoluble rice straw ashes at different temperatures do not strictly follow the order mentioned above. The reason is that the contents of these elements present different changing trends with the increase of the ashing temperature.

As shown in Table 2, the major ingredients of both original ashes and insoluble ashes are $\mathrm{O}$ and $\mathrm{Si}$ (the sum of mass fractions of them $>60 \%$ ) at different ashing temperatures. The contents of $\mathrm{K}, \mathrm{Na}, \mathrm{Ca}$, $\mathrm{Mg}, \mathrm{Cl}, \mathrm{P}$, and $\mathrm{S}$ in the water-insoluble ashes are basically higher than these in the acid-insoluble ashes, indicating that some compounds consisting of these elements are only soluble in acid solution but not insoluble in deionized water [11].

The XRF measurement data of two insoluble ashes in Table 2 also show that the mass fractions of $\mathrm{K}$ increase with increasing the ashing temperature. This is due to the following two reasons [7]: (1) the high temperature makes soluble salts transform into different insoluble silicate compounds, and some key reactions can see the reference [46]; and (2) the sintered materials or insoluble components on the surface of rice straw ash particles prevent internal substances from dissolving in the deionized water.

\subsection{Comparisons of Acid and Water Solubilities of Rice Straw Ashes}

Two solubilities of rice straw ashes, created at different ashing temperatures, in the acetic acid solution and the deionized water are shown in Figure 4. It can be seen that they are significantly lower than the water solubility (61\%) of fly ash from straw combustion [47]. This can be attributed to the release of many soluble substances. It can be also found from the Figure 4 that the acid solubilities (45.3-11.1\%) of the ashes in the acetic acid solution are approximately $5-15 \%$ higher than the corresponding water solubilities (37.5-6.3\%) of those in the deionized water in the temperature range of $400-800^{\circ} \mathrm{C}$. However, their values are low and more than $50 \%$ of rice straw ash is insoluble in the acetic acid solution and the deionized water. According to the literature [21], for the same biomass ash sample, the total dissolved mass content increased by $500 \%$ with the increased acidity of aqueous solutions (the $\mathrm{pH}$ value decreased from 13 to 5). This means that most of the ash-forming elements are acid-soluble, Zevenhoven-Onderwater et al. [48] also confirmed this result. For example, some compounds (e.g., $\mathrm{CaCO}_{3}, \mathrm{MgCO}_{3}$ ) are acid-soluble but water-insoluble. In our experiments, we found that there is gas escaping from the solution while the acetic acid solution is added into the water-insoluble ash. The possible reactions of this phenomenon are R1.

$$
\begin{aligned}
& \mathrm{CaCO}_{3}(\mathrm{~s})+2 \mathrm{CH}_{3} \mathrm{COOH}(\mathrm{aq}) \rightarrow 2 \mathrm{CH}_{3} \mathrm{COO}^{-}+\mathrm{Ca}^{2+}+\mathrm{H}_{2} \mathrm{O}(\mathrm{l})+\mathrm{CO}_{2}(\mathrm{~g}) \\
& \mathrm{MgCO}_{3}(\mathrm{~s})+2 \mathrm{CH}_{3} \mathrm{COOH}(\mathrm{aq}) \rightarrow 2 \mathrm{CH}_{3} \mathrm{COO}^{-}+\mathrm{Mg}^{2+}+\mathrm{H}_{2} \mathrm{O}(\mathrm{l})+\mathrm{CO}_{2}(\mathrm{~g})
\end{aligned}
$$




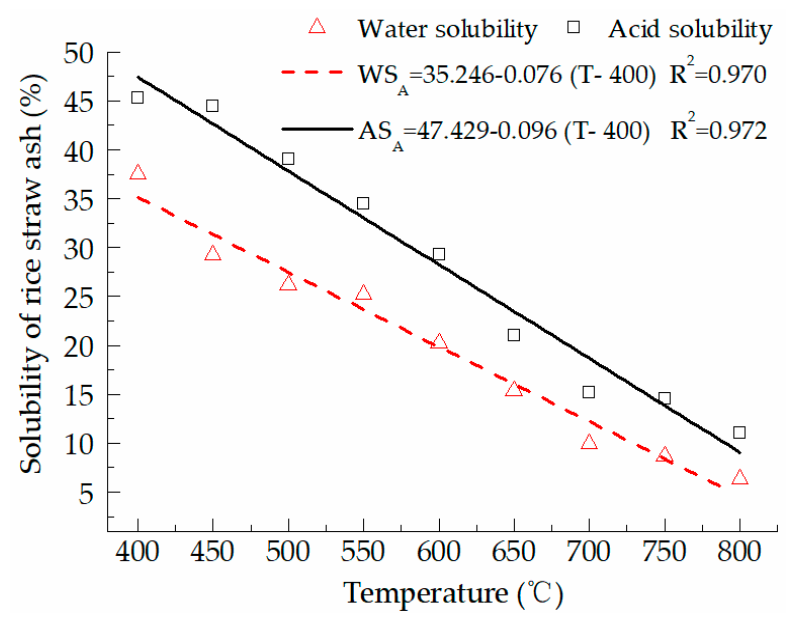

Figure 4. Solubilities of rice straw ash in acetic acid and water at different ashing temperatures. $\mathrm{WS}_{\mathrm{A}}$ is the water solubility of the ash; $\mathrm{AS}_{\mathrm{A}}$ is the acid solubility of the ash; $\mathrm{T}$ is temperature; $\mathrm{R}^{2}$ is determination coefficient.

Additionally, the Figure 4 also shows that as the ashing temperature increases from $400{ }^{\circ} \mathrm{C}$ to $800{ }^{\circ} \mathrm{C}$, two solubilities of rice straw ash decrease by about $70-80 \%$. To further clarify the relationship between the ash solubility and the ashing temperature, the functional dependencies and determination coefficients between the solubilities of rice straw ash and the ashing temperature are given in Figure 4 . It is found that a close negative linear relationship exists between the solubility (including acid solubility and water solubility) of rice straw ash and the ashing temperature. This suggests that a low temperature combustion is more beneficial to the resource utilization of straw ash as a fertilizer.

One of the main reasons for the decline is the severe sintering of straw ash at high temperature [49,50]. The ash sintering leads to the transformation of $\mathrm{Ca}$ and $\mathrm{Mg}$ in the ashes from oxides or sulphates to acid-insoluble Ca-silicate, Ca-Mg-silicate [7], and the melted insoluble inorganic components covering the soluble nutrients [22]. Some important reactions are seen in R2 [7,51].

$$
\begin{gathered}
2 \mathrm{CaO}+\mathrm{SiO}_{2} \rightarrow \mathrm{Ca}_{2} \mathrm{SiO}_{4} \\
2 \mathrm{CaSiO}+\mathrm{MgO} \rightarrow \mathrm{Ca}_{2} \mathrm{MgSi}_{2} \mathrm{O}_{7} \\
14 \mathrm{CaSiO}_{3}+2 \mathrm{MgO} \rightarrow 2 \mathrm{Ca}_{7} \mathrm{Mg}\left(\mathrm{SiO}_{4}\right)_{4}+6 \mathrm{SiO}_{2} \\
3 \mathrm{CaSO}_{4}+\mathrm{Ca}_{3} \mathrm{Al}_{2} \mathrm{O}_{6}+32 \mathrm{H}_{2} \mathrm{O} \rightarrow \mathrm{Ca}_{6} \mathrm{Al}_{2}\left(\mathrm{SO}_{4}\right)_{3}(\mathrm{OH})_{12} \cdot 26 \mathrm{H}_{2} \mathrm{O}
\end{gathered}
$$

Besides ash sintering, the decreasing of both solubilities are also attributed to the release $[7,38]$ or the transformation [52] of partially soluble compounds (e.g., $\mathrm{HCl}(\mathrm{g}), \mathrm{SO}_{3}(\mathrm{~g}), \mathrm{MCl}(\mathrm{g})$ and $\mathrm{MOH}(\mathrm{g})$, where $\mathrm{M}$ represents $\mathrm{K}$ and $\mathrm{Na}$, similarly hereinafter). According to the reference [2], approximately $80-98 \%$ of $\mathrm{Cl}$ is released between $700{ }^{\circ} \mathrm{C}$ and $800{ }^{\circ} \mathrm{C}$, and $40 \%$ of the total $\mathrm{K}$ is released at $800{ }^{\circ} \mathrm{C}$. For S, $25-35 \%$ is released to the gas phase at $500{ }^{\circ} \mathrm{C}$, and up to $40-50 \%$ when the combustion temperature increases from $500{ }^{\circ} \mathrm{C}$ to $800{ }^{\circ} \mathrm{C}$. The potential reactions are listed below as R3 [7].

$$
\begin{gathered}
2 \mathrm{MCl}(\mathrm{g})+n \mathrm{SiO}_{2}(\mathrm{~s}, \mathrm{l})+\mathrm{H}_{2} \mathrm{O}(\mathrm{g}) \rightarrow \mathrm{M}_{2} \mathrm{O} \cdot n \mathrm{SiO}_{2}(\mathrm{~s}, \mathrm{l})+2 \mathrm{HCl}(\mathrm{g}) \\
2 \mathrm{MCl}(\mathrm{g})+n \mathrm{SiO}_{2}(\mathrm{~s}, \mathrm{l})+\mathrm{Al}_{2} \mathrm{O}_{3}(\mathrm{~s}, \mathrm{l})+\mathrm{H}_{2} \mathrm{O}(\mathrm{g}) \rightarrow 2 \mathrm{MAlSi}_{n / 2} \mathrm{O}_{2+n}(\mathrm{~s}, \mathrm{l})+2 \mathrm{HCl}(\mathrm{g}) \\
\mathrm{M}_{2} \mathrm{CO}_{3}(\mathrm{~s}, 1)+\mathrm{H}_{2} \mathrm{O}(\mathrm{g}) \rightarrow 2 \mathrm{MOH}(\mathrm{g})+\mathrm{CO}_{2}(\mathrm{~g}) \\
\mathrm{M}_{2} \mathrm{SO}_{4}(\mathrm{~g})+n \mathrm{SiO}_{2}(\mathrm{~s}, \mathrm{l}) \rightarrow \mathrm{M}_{2} \mathrm{O} \cdot n \mathrm{SiO}_{2}(\mathrm{~s}, 1)+\mathrm{SO}_{3}(\mathrm{~g}) \\
\mathrm{M}_{2} \mathrm{SO}_{4}(\mathrm{~g})+n \mathrm{SiO}_{2}(\mathrm{~s}, \mathrm{l})+\mathrm{Al}_{2} \mathrm{O}_{3}(\mathrm{~s}, \mathrm{l}) \rightarrow 2 \mathrm{MAlSi}_{n / 2} \mathrm{O}_{2+n}(\mathrm{~s}, \mathrm{l})+\mathrm{SO}_{3}(\mathrm{~g})
\end{gathered}
$$

\subsection{Comparisons of Acid and Water Solubilities of Major Elements}

It is well known that crop straw ash contains some essential nutrients and beneficial elements (e.g., $\mathrm{Na}, \mathrm{Si}$ ), which can contribute to plant growth. The essential nutrients can be classified into three types: (1) macronutrients (K, P); (2) medium nutrients (Ca, Mg, S); and (3) micronutrients (Cl). In this 
section, the acid and water solubilities of $\mathrm{K}, \mathrm{P}, \mathrm{Ca}, \mathrm{Mg}, \mathrm{S}, \mathrm{Cl}$, and $\mathrm{Na}$ are analyzed. Of note, according to our experimental data, $\mathrm{Si}$ is almost insoluble in both the acetic acid solution and the deionized water, so it will not be discussed in this section.

\subsubsection{Solubility of Macronutrients}

$\mathrm{K}$ and $\mathrm{P}$ are indispensable as essential nutrients for the growth of organisms in the ecosystem. In general, $\mathrm{K}$ in biomass ash is mainly in the form of $\mathrm{KCl}, \mathrm{K}_{2} \mathrm{SO}_{4}$ and $\mathrm{K}_{2} \mathrm{CO}_{3}$ [53] as well as potassium silicate, aluminosilicate, and sulphate $\left(\mathrm{K}_{2} \mathrm{Ca}\left(\mathrm{SO}_{4}\right)_{2}, \mathrm{~K}_{3} \mathrm{Na}\left(\mathrm{SO}_{4}\right)_{2}\right)$ [54]. P is mainly in the form of phosphates.

The acid and water solubilities of macronutrients $\mathrm{K}$ in rice straw ashes prepared at different ashing temperatures are shown in Figure 5. As shown in Figure 5, the acid solubility of $\mathrm{K}$ is about $6 \%$ higher than its water solubility in the temperature range from $400{ }^{\circ} \mathrm{C}$ to $800{ }^{\circ} \mathrm{C}$. This can be explained as follows: (1) some sintered compounds in the ashes, such as the mixture of potassium-rich silicate and phosphate melts [55,56], are only acid-soluble; (2) the transport channels of some internal K may be occluded by some of acid-soluble salts in the surface of ash particles formed during the rice straw powder combustion [17]. Moreover, Liu et al. [57] indicated that $93 \%$ of $\mathrm{K}$ in rice straw is mainly enriched by acid-soluble salts, and $73 \%$ of $\mathrm{K}$ is water-soluble in rice straw. This trend is similar to the results of $\mathrm{K}$ solubilities contained in rice straw ash in this paper.

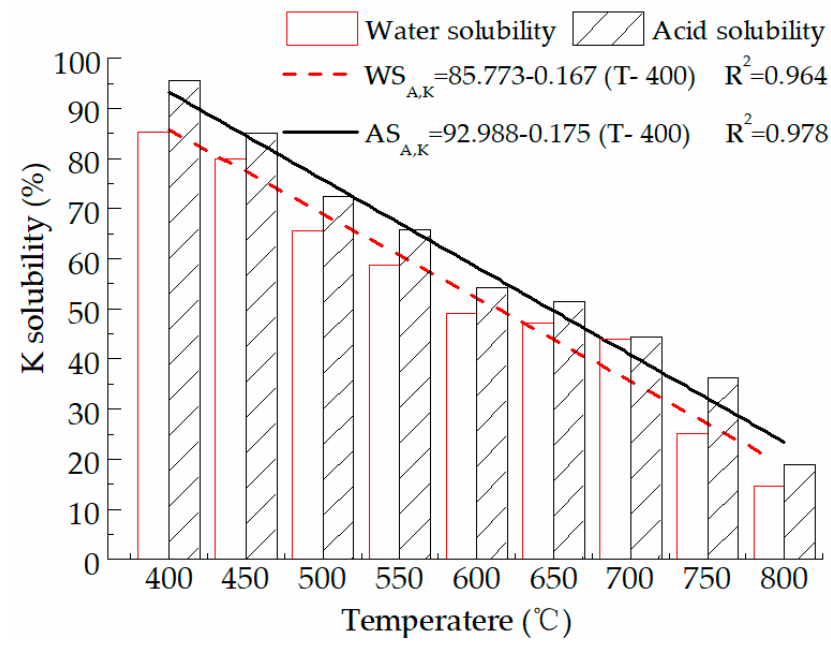

Figure 5. Acid and water solubilities of $\mathrm{K}$ in rice straw ashes at different ashing temperatures. $\mathrm{WS}_{\mathrm{A}, i}$ is the water solubility of element $i$ in the ash; $\mathrm{AS}_{\mathrm{A}, i}$ is the acid solubility of $i$ in the ash.

From the figure, we can also see there is a strong negative linear relationship between the solubility of $\mathrm{K}$ and the ashing temperature. As the temperature increases from $400{ }^{\circ} \mathrm{C}$ to $800{ }^{\circ} \mathrm{C}$, the acid and water solubility of $\mathrm{K}$ decrease linearly by approximately $80 \%$ (from $95.6 \%$ to $18.9 \%$ ) and $83 \%$ (from $85.4 \%$ to $14.7 \%$ ), respectively. Vassilev et al. [11] also reported similar trends in K solubility. Of note, when the ashing temperature is lower than $600{ }^{\circ} \mathrm{C}$, both solubilities are more than $50 \%$, indicating that a lower combustion temperature is beneficial to the recycling application of $\mathrm{K}$ contained in ash in farmland. The main reason of this decrease with temperature, as pointed out in previous works, is the transformation of $\mathrm{K}$ from $\mathrm{K}$-sulphate, $\mathrm{K}$-chloride, and $\mathrm{K}$-hydroxide to $\mathrm{K}$-aluminosilicates via the reactions $\mathrm{R} 3$ and $\mathrm{R} 4[7,37,50,53,58]$.

$$
\begin{gathered}
\mathrm{Al}_{2} \mathrm{O}_{3} \cdot 2 \mathrm{SiO}_{2}+2 \mathrm{KCl}+\mathrm{H}_{2} \mathrm{O} \rightarrow 2 \mathrm{KAlSiO}_{4}+2 \mathrm{HCl} \\
\mathrm{Al}_{2} \mathrm{O}_{3} \cdot 2 \mathrm{SiO}_{2}+2 \mathrm{KCl}+2 \mathrm{SiO}_{2}+\mathrm{H}_{2} \mathrm{O} \rightarrow 2 \mathrm{KAlSi}_{2} \mathrm{O}_{6}+2 \mathrm{HCl} \\
\mathrm{Al}_{2} \mathrm{O}_{3} \cdot 2 \mathrm{SiO}_{2}+2 \mathrm{KOH} \rightarrow 2 \mathrm{KAlSiO}_{4}+\mathrm{H}_{2} \mathrm{O} \\
\mathrm{Al}_{2} \mathrm{O}_{3} \cdot 2 \mathrm{SiO}_{2}+2 \mathrm{KOH}+2 \mathrm{SiO}_{2} \rightarrow 2 \mathrm{KAlSi}_{2} \mathrm{O}_{6}+\mathrm{H}_{2} \mathrm{O}
\end{gathered}
$$


Furthermore, as reported in [17,59], K solubility is determined by the dissolution of $\mathrm{Si}$, and this dissolution rate increases with increasing the $\mathrm{pH}$ value of solution. However, according to the experimental data in both the present study and our previous study [22], $\mathrm{Si}$ in rice straw ash is almost insoluble in the acetic acid solution and the deionized water, but $\mathrm{K}$ is easily soluble. It suggests that $\mathrm{K}$ solubility does not depend on Si solubility. This significant difference of Si solubility in the references and our studies is due to the differences of both the experimental conditions and the characteristics of extraction solutions. Therefore, the correlations between the solubilities of other elements and $\mathrm{Si}$ solubility are not considered and analyzed in this paper.

The acid and water solubilities of macronutrients $\mathrm{P}$ in rice straw ashes prepared at different ashing temperatures are shown in Figure 6. As we can see, when the ashing temperature is less than $600{ }^{\circ} \mathrm{C}$, the acid solubility of $\mathrm{P}$ decreases slowly with the increase of the temperature. When the temperature is higher than $600{ }^{\circ} \mathrm{C}$, the effect of the ashing temperature on the acid solubility of $\mathrm{P}$ is not significant. In addition, Figure 6 indicates that in the whole experimental temperature range $\left(400-800^{\circ} \mathrm{C}\right)$, the acid solubility of $\mathrm{P}$ contained in rice straw ashes is tremendously higher than its water solubility. More than $60 \%$ of $\mathrm{P}$ is acid-soluble at different temperatures, while its water solubility is less than $25 \%$. This indicates that most of phosphates (e.g., $72-80 \%$ of $\mathrm{Ca}_{3}\left(\mathrm{PO}_{4}\right)_{2}, 8-10 \%$ of $\left.\mathrm{Na}_{6}\left(\mathrm{PO}_{4}\right)_{2}\right)[11,60]$ are dissolved in the acetic acid solution through the neutralization reaction of acetic acid and hydroxide ion $\left(\mathrm{OH}^{-}\right)$produced from the hydrolysis of phosphate radical $\left(\mathrm{PO}_{4}^{3-}\right)(\mathrm{R} 5)$.

$$
\mathrm{PO}_{4}^{3-}+\mathrm{H}_{2} \mathrm{O} \leftrightarrow \mathrm{HPO}_{4}^{2-}+\mathrm{OH}_{2} \mathrm{CH}_{3} \mathrm{COOH}+\mathrm{OH}^{-} \rightarrow \mathrm{CH}_{3} \mathrm{COO}^{-}+\mathrm{H}_{2} \mathrm{O}
$$

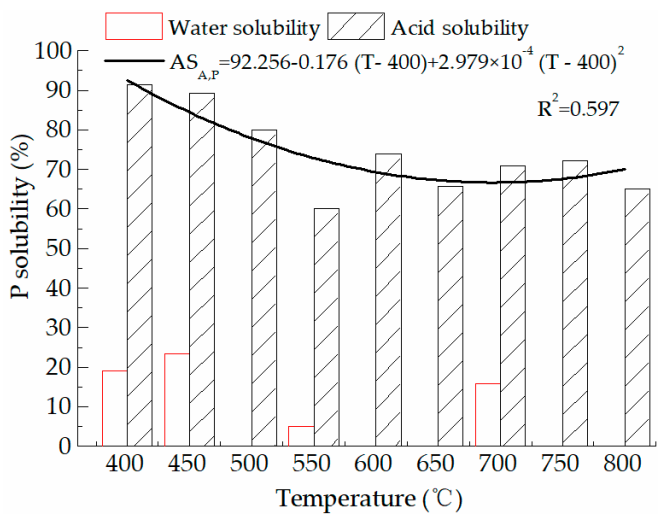

Figure 6. Acid and water solubilities of $\mathrm{P}$ in rice straw ashes at different ashing temperatures.

As Figure 6 shows, the determination coefficient $\left(R^{2}\right)$ of the correlation of the acid solubility with the ashing temperature is equal to 0.597 , which is obviously less than 1.0. Thus, there is not a significant quadratic curve relationship between the acid solubility of $\mathrm{P}$ and the temperature.

\subsubsection{Solubility of Medium and Micronutrients}

The acid and water solubilities of medium nutrients $\mathrm{Ca}, \mathrm{Mg}$, and $\mathrm{S}$ contained in rice straw ashes at different ashing temperatures are presented in Figures 7-9, respectively. As shown in Figures 7 and 8 , the acid solubilities of both $\mathrm{Ca}$ and $\mathrm{Mg}$ are significantly higher than their water solubilities. Both $\mathrm{Ca}$ and $\mathrm{Mg}$ are almost water-insoluble because most of them are in the form of carbonates in the whole experimental temperature range $\left(400-800^{\circ} \mathrm{C}\right)$ [53]. These carbonates are insoluble in water but soluble in acetic acid solution as shown in reaction R1. Especially, when the temperature is less than $600{ }^{\circ} \mathrm{C}$, more than $50 \%$ of both $\mathrm{Ca}$ and $\mathrm{Mg}$ contained in rice straw ash is acid-soluble. 


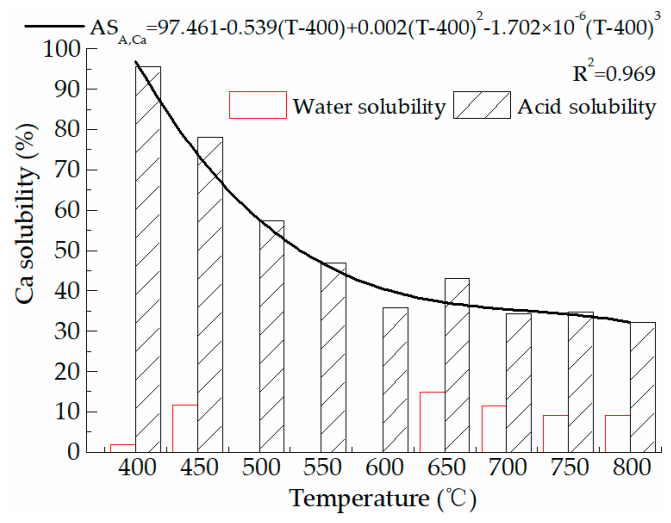

Figure 7. Acid and water solubilities of medium nutrient $\mathrm{Ca}$ at different ashing temperatures.

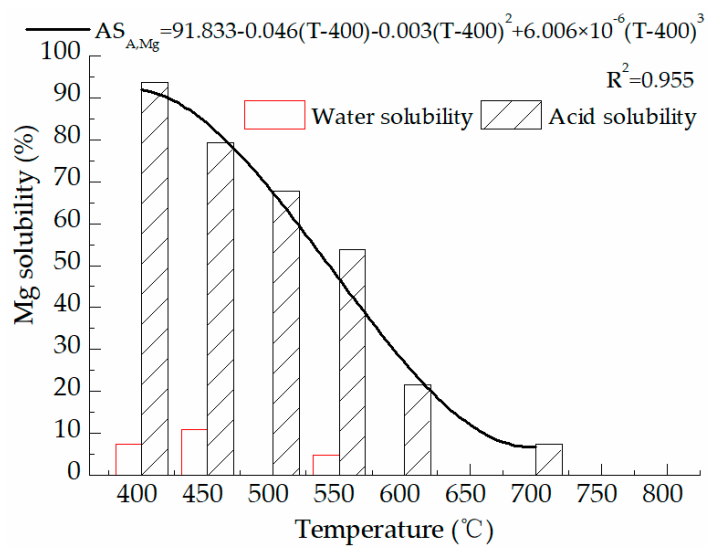

Figure 8. Acid and water solubilities of medium nutrient $\mathrm{Mg}$ at different ashing temperatures.

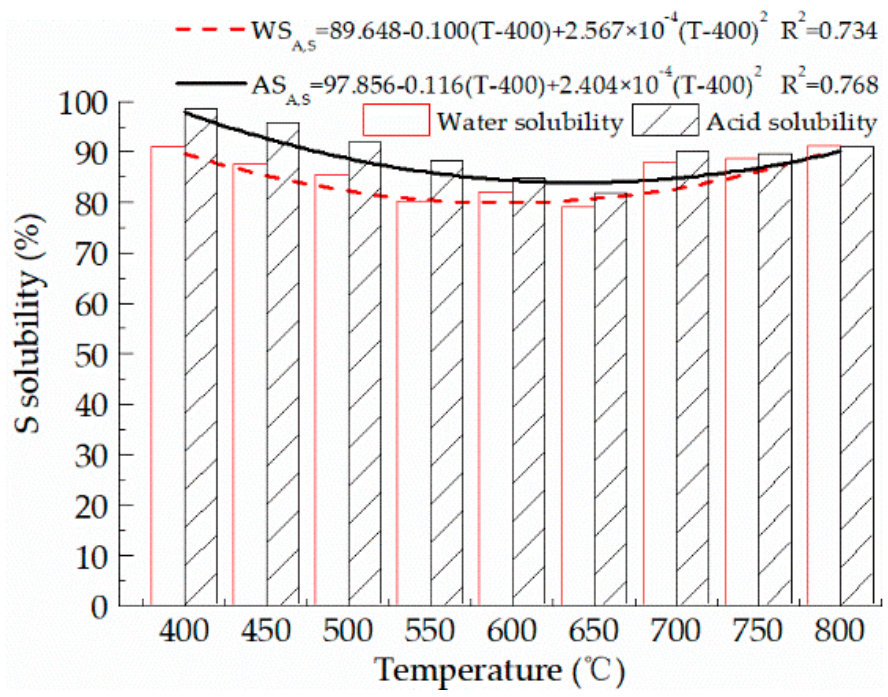

Figure 9. Acid and water solubilities of medium nutrient $S$ at different ashing temperatures.

It is clearly shown in Figures 7 and 8 that a strong cubic curve relationship exists between the acid solubility of $\mathrm{Ca} / \mathrm{Mg}$ and the ashing temperature. When the temperature increases from $400{ }^{\circ} \mathrm{C}$ to $600{ }^{\circ} \mathrm{C}$, the acid solubilities of $\mathrm{Ca}$ and $\mathrm{Mg}$ decrease significantly from $95.68 \%$ to $35.73 \%$ (decrease by about $63 \%$ ) and from $93.69 \%$ to $21.64 \%$ (decrease by about $77 \%$ ), respectively. This change trend is similar to that of P. The partial reason of this decrease, as pointed out in previous works [7], may be that alkaline-earth metals transform into molten silicates (via the equation R4) which coat the surface of straw ash particles to prevent the dissolution of nutrients at high temperature. In addition, the change 
of the acid solubility of $\mathrm{Ca}$ is small as the temperature increases from $600{ }^{\circ} \mathrm{C}$ to $800{ }^{\circ} \mathrm{C}$, indicating that the calcium compounds in the ashes may approach phase equilibrium at the temperatures above $600^{\circ} \mathrm{C}$.

For medium nutrient $\mathrm{S}$, it is mainly concentrated in straw ash in the form of the sulphates of $\mathrm{K}$, $\mathrm{Na}$, etc. [11]. It is well known that most of sulphates are soluble in both the acetic acid solution and the deionized water. As shown in Figure 9, the acid solubility of $S$ contained in the rice straw ashes is slightly higher than the corresponding water solubility at $400-750{ }^{\circ} \mathrm{C}$. The acid and water solubilities of $\mathrm{S}$ are more than $75 \%$ at different temperatures. With the increase of the ashing temperature, the changes of both solubilities are firstly decreased and then slightly increased. Consequently, the effect of the ashing temperature on the solubility of $S$ contained in rice straw ash is slight in different solutions.

Micronutrient $\mathrm{Cl}$ is an important component of rice straw ash. It can form a variety of chlorides with $\mathrm{Ca}, \mathrm{Na}, \mathrm{K}, \mathrm{Zn}$, etc. [11] and they are the main forms of $\mathrm{Cl}$ in rice straw ashes at different ashing temperatures. Like the sulphates, the chlorides are also soluble in the acetic acid solution and the deionized water.

Figure 10 describes the acid and water solubilities of micronutrient $\mathrm{Cl}$ contained in rice straw ashes prepared at different ashing temperatures. As we can see, both the acid and water solubilities of $\mathrm{Cl}$ are higher than $75 \%$ in the ashing temperature range of $400-700{ }^{\circ} \mathrm{C}$. In this temperature range, two solubilities of $\mathrm{Cl}$ are slightly decreased with the increase of the temperature. However, when the temperature is higher than $700{ }^{\circ} \mathrm{C}$, two solubilities of $\mathrm{Cl}$ contained in the rice straw ashes decrease rapidly. The reason for that is that most of $\mathrm{Cl}$ in the ashes are released, as shown in Table 2.

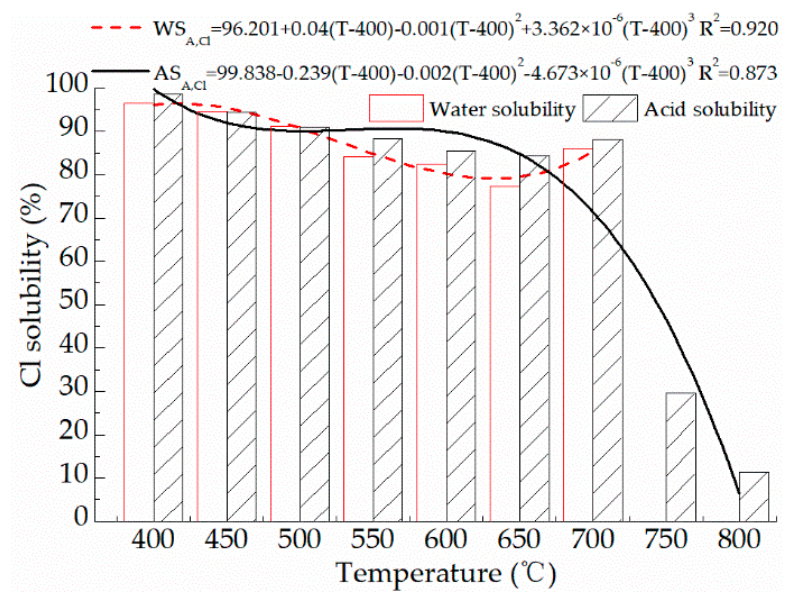

Figure 10. Acid and water solubilities of micronutrient $\mathrm{Cl}$ at different ashing temperatures.

\subsubsection{Solubility of Beneficial Element}

The acid and water solubilities of beneficial element Na contained in rice straw ashes prepared at different ashing temperatures are shown in Figure 11. It can be seen that the acid solubilities of $\mathrm{Na}$ contained in the ashes are about $4-7 \%$ higher than the corresponding water solubilities at different temperatures. 


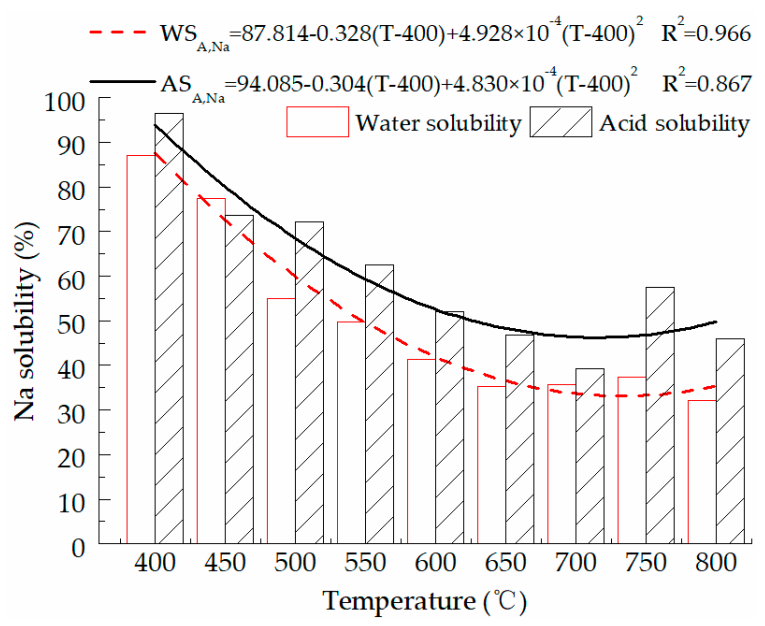

Figure 11. Acid and water solubility of beneficial element $\mathrm{Na}$ at different ashing temperatures.

Figure 11 also shows that there is a close quadratic curve relationship between the solubility of $\mathrm{Na}$ and the temperature. The acid and water solubility of Na decrease gradually from about $96 \%$ to $39 \%$ and from about $87 \%$ to $32 \%$ with increasing the temperature, respectively. The reasons for these decreases are similar to those of $\mathrm{K}$.

From the comparison results of two solubilities of different nutrient elements mentioned above, it is not difficult to find that the acid solubilities of the major ash-forming elements are always higher than the water solubilities of those. When the ashing temperature is less than $600{ }^{\circ} \mathrm{C}$, their solubilities are basically higher than 50\%. Especially, most of $\mathrm{P}, \mathrm{Ca}$, and $\mathrm{Mg}$ are acid-soluble but water-insoluble. This conclusion is also confirmed by some previous work $[23,24]$. Hence, to better realize the closed cycle of nutrients in rice straw, the following two principles should be followed: (1) the ashing temperature should not be higher than $600^{\circ} \mathrm{C}$, (2) the rice straw ash should be applied to acidic soil.

\section{Conclusions}

The acid solubilities of rice straw ash together with its major ash-forming elements in the ashing temperature range of $400-800{ }^{\circ} \mathrm{C}$ have been experimentally studied and compared with the corresponding water solubilities of them in this paper. The main results are as follows:

- The acid solubility of rice straw ash is approximately $5-15 \%$ higher than the water solubility of that in the experimental temperature range. Two solubilities of the ash decrease linearly with the increase of the ashing temperature, and the acid solubility of the ash decreases by about $76 \%$ when the temperature increases from $400{ }^{\circ} \mathrm{C}$ to $800{ }^{\circ} \mathrm{C}$.

- The acid and water solubility of $\mathrm{K}$ decreases linearly by approximately $80 \%$ and $83 \%$ as the ashing temperature increases, respectively. The acid solubility of $\mathrm{K}$ is about $6 \%$ higher than its water solubility. P, S, and Na solubilities with the temperature have quadratic curve relationships. The solubilities of $\mathrm{Ca}, \mathrm{Mg}$, and $\mathrm{Cl}$ have significant cubic curve correlations with the temperature.

- $\mathrm{P}, \mathrm{Ca}$, and $\mathrm{Mg}$ are soluble in the acetic acid solution but almost insoluble in the deionized water. The solubilities of $\mathrm{K}, \mathrm{P}, \mathrm{Ca}, \mathrm{Mg}$, and $\mathrm{Na}$ vary obviously with increasing the temperature, and the acid solubilities of them are higher than the corresponding water solubilities. Whereas two solubilities of $\mathrm{S}$ and $\mathrm{Cl}$ are slightly affected by the ashing temperature.

- When the ashing temperature of rice straw is lower than $600^{\circ} \mathrm{C}$, the rice straw ash will have a more accessible (soluble or bioavailable) nutrient content. Otherwise, most nutrients contained in the ash will be sintered or released with the flue gas.

It can be concluded that the recycling property of the nutrients in rice straw ash is significantly affected by the combustion temperature and the acidity of solution. A lower combustion temperature and a lower $\mathrm{pH}$ value can lead to a better recycling property of the nutrients in straw ash. In other 
words, the application of straw ash produced from low-temperature in acid soil will have a better prospect. This can not only contribute to the sustainable application of biomass energy, but also reduce the amount of utilization of chemical fertilizer, the area of acid soil and the cost of agricultural production, thus achieving the sustainable development of modern agriculture. Therefore, low temperature combustion technology for biomass should be considered and developed, and some fundamental studies on recycling of straw ash as a fertilizer to agricultural land should be also strengthened in the future.

\section{Patents}

According to the above conclusion that the low temperature combustion technology of biomass can be beneficial to the recycling utilization of biomass ash as a fertilizer in farmland, a patent for invention of a method and device for low-temperature solid phase, high-temperature gas phase combustion of biomass briquette fuel has been applied by the authors, and it has been authorized by the State Intellectual Property Office of the P.R.C (Patent no. CN 201710174853.0).

Author Contributions: Conception of the idea, Y.Z., G.Z., and F.H.; Methodology of the study, Y.Z. and G.Z.; Material collection and treatment, Y.Z.; Data curation, Y.Z.; Result analysis, Y.Z. and F.H.; Writing-original draft preparation, Y.Z.; Writing—review and editing, Y.Z., M.W., M.T., Z.G., G.Z., and F.H.; Funding acquisition, G.Z. and F.H.; Contributed equally, G.Z. and F.H.

Funding: This research was funded by two National Natural Science Foundations of China, grant numbers 51576115 and 51676115.

Acknowledgments: The authors gratefully acknowledge financial support from the National Natural Science Foundation of China (51576115) and the National Natural Science Foundation of China (51676115).

Conflicts of Interest: The authors declare no conflict of interest.

\section{References}

1. Brannvall, E.; Wolters, M.; Sjoblom, R.; Kumpiene, J. Elements availability in soil fertilized with pelletized fly ash and biosolids. J. Environ. Manag. 2015, 159, 27-36. [CrossRef]

2. Väätäinen, K.; Sirparanta, E.; Räisänen, M.; Tahvanainen, T. The costs and profitability of using granulated wood ash as a forest fertilizer in drained peatland forests. Biomass Bioenergy 2011, 35, 3335-3341. [CrossRef]

3. Zhang, Z.; He, F.; Zhang, Y.; Yu, R.; Li, Y.; Zheng, Z.; Gao, Z. Experiments and modelling of potassium release behavior from tablet biomass ash for better recycling of ash as eco-friendly fertilizer. J. Clean. Prod. 2018, 170, 379-387. [CrossRef]

4. Memon, S.A.; Wahid, I.; Khan, M.K.; Tanoli, M.A.; Bimaganbetova, M. Environmentally Friendly Utilization of Wheat Straw Ash in Cement-Based Composites. Sustainability 2018, 10, 1322. [CrossRef]

5. Payá, J.; Roselló, J.; Monzó, J.M.; Escalera, A.; Santamarina, M.P.; Borrachero, M.V.; Soriano, L. An Approach to a New Supplementary Cementing Material: Arundo donax Straw Ash. Sustainability 2018, 10, 4273. [CrossRef]

6. Novais, R.M.; Ascensão, G.; Tobaldi, D.M.; Seabra, M.P.; Labrincha, J.A. Biomass fly ash geopolymer monoliths for effective methylene blue removal from wastewaters. J. Clean. Prod. 2018, 171, 783-794. [CrossRef]

7. Niu, Y.; Tan, H.; Hui, S. Ash-related issues during biomass combustion: Alkali-induced slagging, silicate melt-induced slagging (ash fusion), agglomeration, corrosion, ash utilization, and related countermeasures. Prog. Energy Combust. Sci. 2016, 52, 1-61. [CrossRef]

8. Rosales, J.; Cabrera, M.; Beltrán, M.G.; López, M.; Agrela, F. Effects of treatments on biomass bottom ash applied to the manufacture of cement mortars. J. Clean. Prod. 2017, 154, 424-435. [CrossRef]

9. Prasara-A, J.; Gheewala, S.H. Sustainable utilization of rice husk ash from power plants: A review. J. Clean. Prod. 2017, 167, 1020-1028. [CrossRef]

10. Nunes, L.J.R.; Matias, J.C.O.; Catalão, J.P.S. Biomass combustion systems: A review on the physical and chemical properties of the ashes. Renew. Sustain. Energy Rev. 2016, 53, 235-242. [CrossRef] 
11. Vassilev, S.V.; Baxter, D.; Andersen, L.K.; Vassileva, C.G. An overview of the composition and application of biomass ash. Part 1. Phase-mineral and chemical composition and classification. Fuel 2013, 105, 40-76. [CrossRef]

12. Ekvall, H.; Löfgren, S.; Bostedt, G. Ash recycling-A method to improve forest production or to restore acidified surface waters? For. Policy Econ. 2014, 45, 42-50. [CrossRef]

13. Bonanno, G.; Cirelli, G.L.; Toscano, A.; Giudice, R.L.; Pavone, P. Heavy metal content in ash of energy crops growing in sewage-contaminated natural wetlands: Potential applications in agriculture and forestry? Sci. Total Environ. 2013, 452-453, 349-354. [CrossRef]

14. Nurmesniemi, H.; Mäkelä, M.; Pöykiö, R.; Manskinen, K.; Dahl, O. Comparison of the forest fertilizer properties of ash fractions from two power plants of pulp and paper mills incinerating biomass-based fuels. Fuel Process. Technol. 2012, 104, 1-6. [CrossRef]

15. Freire, M.; Lopes, H.; Tarelho, L.A.C. Critical aspects of biomass ashes utilization in soils: Composition, leachability, PAH and PCDD/F. Waste Manag. 2015, 46, 304-315. [CrossRef]

16. Kalembkiewicz, J.; Chmielarz, U. Ashes from co-combustion of coal and biomass: New industrial wastes. Resour. Conserv. Recycl. 2012, 69, 109-121. [CrossRef]

17. Nguyen, M.N.; Dultz, S.; Picardal, F.; Bui, A.T.; Van, P.Q.; Schieber, J. Release of potassium accompanying the dissolution of rice straw phytolith. Chemosphere 2015, 119, 371-376. [CrossRef]

18. Vassilev, S.V.; Baxter, D.; Andersen, L.K.; Vassileva, C.G. An overview of the composition and application of biomass ash.: Part 2. Potential utilisation, technological and ecological advantages and challenges. Fuel 2013, 105, 19-39. [CrossRef]

19. Li, S.; Liu, Y.; Wang, J.; Yang, L.; Zhang, S.; Xu, C.; Ding, W. Soil Acidification Aggravates the Occurrence of Bacterial Wilt in South China. Front. Microbiol. 2017, 8, 1-12. [CrossRef] [PubMed]

20. Blake, L. Acid Rain and Soil Acidification. In Encyclopedia of Soils in the Environment; Hillel, D., Ed.; Elsevier: Oxford, UK, 2005; pp. 1-11.

21. Etiégni, L.; Campbell, A.G. Physical and chemical characteristics of wood ash. Bioresour. Technol. 1991, 37, 173-178. [CrossRef]

22. Zhang, Y.; He, F.; Gao, Z.; You, Y.; Sun, P. Effects of ash-forming temperature on recycling property of bottom ashes from rice residues. Fuel 2015, 162, 251-257. [CrossRef]

23. Andrea Jordan, C.; Akay, G. Speciation and distribution of alkali, alkali earth metals and major ash-forming elements during gasification of fuel cane bagasse. Fuel 2012, 91, 253-263. [CrossRef]

24. Werkelin, J.; Skrifvars, B.-J.; Zevenhoven, M.; Holmbom, B.; Hupa, M. Chemical forms of ash-forming elements in woody biomass fuels. Fuel 2010, 89, 481-493. [CrossRef]

25. Khanna, P.; Raison, R.; Falkiner, R. Chemical properties of ash derived from Eucalyptus litter and its effects on forest soils. For. Ecol. Manag. 1994, 66, 107-125. [CrossRef]

26. Xing, P.; Mason, P.E.; Chilton, S.; Lloyd, S.; Jones, J.M.; Williams, A.; Nimmo, W.; Pourkashanian, M. A comparative assessment of biomass ash preparation methods using $\mathrm{X}$-ray fluorescence and wet chemical analysis. Fuel 2016, 182, 161-165. [CrossRef]

27. Vassilev, S.V.; Vassileva, C.G.; Song, Y.-C.; Li, W.-Y.; Feng, J. Ash contents and ash-forming elements of biomass and their significance for solid biofuel combustion. Fuel 2017, 208, 377-409. [CrossRef]

28. Katare, V.D.; Madurwar, M.V. Experimental characterization of sugarcane biomass ash-A review. Constr. Build. Mater. 2017, 152, 1-15. [CrossRef]

29. Maresca, A.; Hyks, J.; Astrup, T.F. Recirculation of biomass ashes onto forest soils: Ash composition, mineralogy and leaching properties. Waste Manag. 2017, 70, 127-138. [CrossRef]

30. Zhang, Z.; He, F.; Zhang, Y.; Li, X.; Gao, Z. Simulation of combustion process of a single biomass pellet based on heterogeneous-dimension discretization. J. Energy Inst. 2018. [CrossRef]

31. Ziemiański, L.; Zak, G.; Duda, A.; Wojtasik, M. Modification of the characteristic melting temperatures of sawdust ashes. J. Renew. Sustain. Energy 2017, 9, 043102. [CrossRef]

32. Wang, S.; Hu, Y.; He, Z.; Wang, Q.; Xu, S. Study of pyrolytic mechanisms of seaweed based on different components (soluble polysaccharides, proteins, and ash). J. Renew. Sustain. Energy 2017, 9, 023102. [CrossRef]

33. Trinh, T.K.; Nguyen, T.T.H.; Tu, N.N.; Wu, T.Y.; Meharg, A.A.; Nguyen, M.N. Characterization and dissolution properties of phytolith occluded phosphorus in rice straw. Soil Tillage Res. 2017, 171, 19-24. [CrossRef] 
34. He, F.; Yi, W.; Li, Y.; Zha, J.; Luo, B. Effects of fuel properties on the natural downward smoldering of piled biomass powder: Experimental investigation. Biomass Bioenergy 2014, 67, 288-296. [CrossRef]

35. Van Loo, S.; Koppejan, J. Handbook of Biomass Combustion and Co-Firing; Earthscan: London, UK, 2008.

36. Wang, L.; Skreiberg, Ø.; Becidan, M. Investigation of additives for preventing ash fouling and sintering during barley straw combustion. Appl. Ther. Eng. 2014, 70, 1262-1269. [CrossRef]

37. Chen, C.; Yu, C.; Zhang, H.; Zhai, X.; Luo, Z. Investigation on $\mathrm{K}$ and $\mathrm{Cl}$ release and migration in micro-spatial distribution during rice straw pyrolysis. Fuel 2016, 167, 180-187. [CrossRef]

38. Johansen, J.M.; Aho, M.; Paakkinen, K.; Taipale, R.; Egsgaard, H.; Jakobsen, J.G.; Frandsen, F.J.; Glarborg, P. Release of $\mathrm{K}, \mathrm{Cl}$, and $\mathrm{S}$ during combustion and co-combustion with wood of high-chlorine biomass in bench and pilot scale fuel beds. Proc. Combust. Inst. 2013, 34, 363-2372. [CrossRef]

39. Werther, J.; Saenger, M.; Hartge, E.U.; Ogada, T.; Siagi, Z. Combustion of agricultural residues. Prog. Energy Combust. Sci. 2000, 26, 1-27. [CrossRef]

40. Sluiter, A.; Hames, B.; Ruiz, R.; Scarlata, C.; Sluiter, J.; Templeton, D. Determination of ash in biomass. Nat. Renew. Energy Lab. 2008, 1, 1-5.

41. Febrero, L.; Granada, E.; Patiño, D.; Eguía, P.; Regueiro, A. A Comparative Study of Fouling and Bottom Ash from Woody Biomass Combustion in a Fixed-Bed Small-Scale Boiler and Evaluation of the Analytical Techniques Used. Sustainability 2015, 7, 5819. [CrossRef]

42. Zhang, Y.; Yu, R.; Zhang, Z.; Gao, Z.; Yang, B.; He, F. A comparison on three methods for measuring of water-soluble potassium content in straw ash. Renew. Energy Resour. 2017, 35, 1588-1594.

43. Yu, Y.; Xu, M.; Yao, H.; Yu, D.; Qiao, Y.; Sui, J.; Liu, X.; Cao, Q. Char characteristics and particulate matter formation during Chinese bituminous coal combustion. Proc. Combust. Inst. 2007, 31, 1947-1954. [CrossRef]

44. Luan, C.; You, C.; Zhang, D. Composition and sintering characteristics of ashes from co-firing of coal and biomass in a laboratory-scale drop tube furnace. Energy 2014, 69, 562-570. [CrossRef]

45. Skrifvars, B.-J.; Hupa, M.; Backman, R.; Hiltunen, M. Sintering mechanisms of FBC ashes. Fuel 1994, 73, 171-176. [CrossRef]

46. Niu, Y.; Tan, H.; Wang, X.; Liu, Z.; Liu, H.; Liu, Y.; Xu, T. Study on fusion characteristics of biomass ash. Bioresour. Technol. 2010, 101, 9373-9381. [CrossRef] [PubMed]

47. Lima, A.T.; Ottosen, L.M.; Pedersen, A.J.; Ribeiro, A.B. Characterization of fly ash from bio and municipal waste. Biomass Bioenergy 2008, 32, 277-282. [CrossRef]

48. Zevenhoven-Onderwater, M.; Blomquist, J.P.; Skrifvars, B.J.; Backman, R.; Hupa, M. The prediction of behaviour of ashes from five different solid fuels in fluidised bed combustion. Fuel 2000, 79, 1353-1361. [CrossRef]

49. Boström, D.; Skoglund, N.; Grimm, A.; Boman, C.; Öhman, M.; Broström, M.; Backman, R. Ash Transformation Chemistry during Combustion of Biomass. Energy Fuels 2011, 26, 85-93. [CrossRef]

50. Wang, L.; Hustad, J.E.; Grønli, M. Sintering Characteristics and Mineral Transformation Behaviors of Corn Cob Ashes. Energy Fuels 2012, 26, 5905-5916. [CrossRef]

51. Steenari, B.M.; Karlsson, L.G.; Lindqvist, O. Evaluation of the leaching characteristics of wood ash and the influence of ash agglomeration. Biomass Bioenergy 1999, 16, 119-136. [CrossRef]

52. Du, S.; Yang, H.; Qian, K.; Wang, X.; Chen, H. Fusion and transformation properties of the inorganic components in biomass ash. Fuel 2014, 117, 1281-1287. [CrossRef]

53. Olanders, B.; Steenari, B.-M. Characterization of ashes from wood and straw. Biomass Bioenergy 1995, 8, 105-115. [CrossRef]

54. Magdziarz, A.; Gajek, M.; Nowak-Woźny, D.; Wilk, M. Mineral phase transformation of biomass ashes-Experimental and thermochemical calculations. Renew. Energy 2018, 128, 446-459. [CrossRef]

55. Dan, B.; Skoglund, N.; Grimm, A.; Boman, C.; Öhman, M.; Broström, M.; Backman, R. Ash Transformation Chemistry during Combustion of Biomass. Energy Fuels 2012, 26, 85-93.

56. Hupa, M. Ash-Related Issues in Fluidized-Bed Combustion of Biomasses: Recent Research Highlights. Energy Fuels 2012, 26, 4-14. [CrossRef]

57. Liu, H.; Zhang, L.; Han, Z.; Xie, B.; Wu, S. The effects of leaching methods on the combustion characteristics of rice straw. Biomass Bioenergy 2013, 49, 22-27. [CrossRef]

58. Vassilev, S.V.; Baxter, D.; Vassileva, C.G. An overview of the behaviour of biomass during combustion: Part II. Ash fusion and ash formation mechanisms of biomass types. Fuel 2014, 117, 152-183. [CrossRef] 
59. Nguyen, M.N.; Dultz, S.; Guggenberger, G. Effects of pretreatment and solution chemistry on solubility of rice-straw phytoliths. J. Plant Nutr. Soil Sci. 2014, 177, 349-359. [CrossRef]

60. Thy, P.; Jenkins, B.M.; Lesher, C.E. High-Temperature Melting Behavior of Urban Wood Fuel Ash. Energy Fuels 1999, 13, 839-850. [CrossRef] 